\title{
Fertility After Allogeneic Hematopoietic Stem Cell Transplantation: A 23-Year Review From A Tertiary Hospital
}

\author{
Pinar ATACA ATILLA ${ }^{1}$, Erden ATILLA ${ }^{1}$, Elif EDIBOGLU ${ }^{2}$, Sinem C. BOZDAG ${ }^{1}$, Selami K. TO- \\ PRAK $^{1}$, Onder ARSLAN ${ }^{1}$, Muhit OZCAN $^{1}$,Gunhan GURMAN ${ }^{1}$, Pervin TOPCUOGLU ${ }^{1}$ \\ ${ }^{1}$ Ankara University Faculty of Medicine, Department of Hematology \\ ${ }^{2}$ Ankara University Faculty of Medicine, Department of Internal Medicine, Ankara, TURKEY
}

\begin{abstract}
ABSTARCAT
Infertility is a major late side effect after allogeneic hematopoietic stem cell transplantation (allo-HSCT). However, healthy pregnancies and births were reported previously. We retrospectively evaluated the fertility of 107 adult patients who underwent Allo-HSCT (median age: 32.3) between 1989-2012 at our center and survived 2 years or more after transplantation. From totally 29 pregnancies (21 partners of male patients vs 8 female patients), 6 of the female patients (14\%) and 20 of the male patients (45\%), had a child after Allo-HSCT. The benign nature of the initial diagnosis, lack of chemotherapy regimen before transplantation, early age and no relapse of the primary disease contribute to fertility in our study. No relation was detected between the myeloablative conditioning regimen, radiotherapy prior to Allo-HSCT, TBI usage and frequency, and development of acute and chronic GVHD with infertility.
\end{abstract}

Keywords: Allogeneic stem cell transplantation, Fertility

\section{ÖZET}

Allojeneik Hematopoietik Kök Hücre Nakli Sonrasinda Fertilite: Üçüncü Basamak Hastanenin 23 Yıllık Veri DerlemesiAllojeneik kök hücre nakli (AKHN) sonrası en önemli uzun dönem yan etkilerden birisi infertilitedir. Fakat, daha önceki çalışmalarda sağlıklı gebelikler ve doğumlar bildirilmiştir. 1989-2012 yılları arasında merkezimizde AKHN yapılmış ve transplantasyon sonrası 2 yıl ve üzeri yaşayan 107 erişkin hasta (ortanca yaş: 32,3) retrospektif olarak değerlendirilmiştir. 29 gebelikten (21 erkek hastaların eşlerinden, 8 kadın hasta), 6 kadın hasta (\%14) ve 20 erkek hastanın eşi (\%45) AKHN sonrasında çocuk sahibi olmuştur. Tanı anında benign karakterde hastalık, transplantasyon öncesi kemoterapi almamıș olmak, erken yaș, primer hastalığın nüksünün olmaması fertilite ile ilişkili olarak bulunmuştur. Myeloablatif hazırlık rejimi, AKHN öncesi radyoterapi, TBı kullanımı ve sıklığı, akut veya kronik graft versus host hastalığı fertilite ile ilişkili değildir.

Anahtar Kelimeler: Allojeneik kök hücre nakli, Fertilite 


\section{INTRODUCTION}

Allogeneic hematopoietic stem cell transplantation (allo-HSCT) has become the gold standard curative approach for a variety of hematological disorders. The overall survival and cure rates of patients with hematological malignancies have improved dramatically with modern antitumor modalities including allo-HSCT.

Today, attention is focused on late transplant-related complications, including those that are lifethreatening but also those that may worsen patient quality of life. ${ }^{1}$ Loss of fertility affects quality of life in transplant survivors. Infertility is an essential issue for healthcare professionals dealing with cancer patients. Borgmann-Staudt et al. reported that impaired fertility was observed 3-12 years after the treatment in $69 \%$ of male patients and $83 \%$ of female patients who received allo-HSCT at an early age. ${ }^{2}$ High doses of alkylating agents and/or total body irradiation (TBI) as well as older age in women at the time of transplant were found to be related to gonadal dysfunction and infertility. ${ }^{3}$ Recovery of fertility after HSCT therapy has been reported in both sexes; in males the rate of spermatogenesis may increase with time. ${ }^{4}$ Successful pregnancies after HCST have been reported in previous studies. ${ }^{5}$ In this study, we investigated the pregnancy outcomes and factors related to infertility in our patients after allo-HSCT.

\section{PATIENTS AND METHODS}

We retrospectively evaluated the fertility of 107 eligible patients who underwent allo-HSCT and survived 2 years or more after the transplantation between 1989-2012 in the Department of Adult Hematology at Ankara University. All patients gave their written informed consent for participation in the study, which was approved by the local Ethical Committee. Patients and transplant data were collected using electronic clinical records. Our clinical records consist of disease status, treatment lines and types, conditioning regimens, graft versus host disease (GVHD) state, complications and fertility. Data on ovarian function and fertility was evaluated in female by serum levels of follicle-stimulating hormone (FSH) and luteinizing hormone (LH) measured at day 2 or 3 of the cycle in patients with spontaneous menses or during amenorrhea in others. In male patients who wanted to have a child from their partner the serum levels of FSH, LH and testosterone and spermiogram analysis were done. Detailed data regarding pregnancies and complications before or after allo-HSCT were collected from the patient or patient's spouse by phone calls and/or clinical visits. The stem cell sources for transplants were bone marrow (32.7\%) or peripheral blood $(61.3 \%)$. Donors were HLA-matched related $(96.3 \%)$ or HLA-matched or mismatch unrelated $(2.7 \%)$. Myeloablative $(92.5 \%)$ or reduced intensity $(7.5 \%)$ conditioning regimens were preferred due to patient status and underlying disease. All patients received prophylaxis for GVHD and infections. None of the patients or partners of the patients included in this study were using any of the contraception method.

\section{Statistical Analysis}

All of the numerical values were given as the median with the distribution range. We used the Pearson chi-square test or Fisher exact test to compare categorical variable. $\mathrm{P}<0.05$ was considered statistically significant.

\section{RESULTS}

In 107 patients (44 Female/63 Male), the median age at the time of study participation was 41.2 (range, 22-59 years), whereas the median age at allo-HSCT was 32.3 (range, 16-45 years). Seventy-one of 107 patients $(66 \%)$ were 30 years or older at the time of allo-HSCT. The median length of follow-up time after allo-HSCT was 86 months (range, 28-237 months). The patient characteristics are shown in Table 1. Thirteen of the 107 patients had no history of chemotherapy or radiotherapy prior to allo-HSCT. Only 3 patients had received radiotherapy before allo-HSCT apart from what was contained in the conditioning regimen. A myeloablative conditioning regimen was preferred in 40 of the female patients (91\%) and 59 of the male patients( $94 \%)$. The most common site of acute GVHD was skin in women $(41 \%)$, whereas both skin and gastrointestinal system (48\%) complications were observed in men. Chronic GVHD with liver involvement was the most common oc- 


\begin{tabular}{|c|c|c|c|}
\hline Variables & Female $(n=44)$ & Male $(n=63)$ & $\mathbf{P}$ \\
\hline \multicolumn{4}{|l|}{ Age } \\
\hline $\begin{array}{l}\text { Median age at Allo-HSCT, } \\
\text { years (range) }\end{array}$ & 32.3 (16-45 years) & 32.4 (16-45 years) & $>0.05$ \\
\hline Age $\geq 30$ at AlloHSCT, n (\%) & $30(68 \%)$ & $41(65 \%)$ & \\
\hline \multicolumn{4}{|l|}{ Diagnosis, n (\%) } \\
\hline Acute leukemia & $21(48 \%)$ & $36(57 \%)$ & $>0.05$ \\
\hline Chronic myeloproliferative disease & $12(27 \%)$ & $20(32 \%)$ & \\
\hline Bone marrow failure & $8(18 \%)$ & $2(0.3 \%)$ & \\
\hline Other & $3(0.7 \%)$ & $5(0.8 \%)$ & \\
\hline \multicolumn{4}{|l|}{ Donor, n (\%) } \\
\hline HLA-matched relative & 41 (93. 2\%) & $62(98.4 \%)$ & $>0.05$ \\
\hline $\begin{array}{l}\text { HLA-matched or mismatched } \\
\text { non-relative }\end{array}$ & $3(6.8 \%)$ & $1(2.6 \%)$ & \\
\hline \multicolumn{4}{|l|}{ Stem Cell Source, n (\%) } \\
\hline Bone Marrow & $14(32 \%)$ & $21(34 \%)$ & $>0.05$ \\
\hline Peripheral Blood & $30(68 \%)$ & $42(66 \%)$ & \\
\hline \multicolumn{4}{|l|}{ Conditioning Regimen, n (\%) } \\
\hline Cyclophosphamide & 40 (91\%) & 58 (92\%) & $>0.05$ \\
\hline ATG (antithymocyte globulin) & $11(25 \%)$ & $6(10 \%)$ & \\
\hline Fludarabine & $6(14 \%)$ & $7(11 \%)$ & \\
\hline Busulphan & 35 (80\%) & 47 (75\%) & \\
\hline TBI (total body irradiation) & $3(7 \%)$ & $10(16 \%)$ & \\
\hline \multicolumn{4}{|l|}{ Development of GVHD, n (\%) } \\
\hline Acute GVHD & 15 (34\%) & $25(40 \%)$ & $>0.05$ \\
\hline Chronic GVHD & $25(57 \%)$ & $39(62 \%)$ & \\
\hline $\begin{array}{l}\text { Relapse of primary disease after } \\
\text { Allo-HSCT, n (\%) }\end{array}$ & $11(25 \%)$ & $20(32 \%)$ & $>0.05$ \\
\hline
\end{tabular}

currence in both females $(38 \%)$ and males $(32 \%)$. Median time to relapse of the primary hematological disease after allo-HCST was 32 months. During follow-up, 21 patients died of primary disease relapse.

Median age, diagnosis, donor type, stem cell source, conditioning regimen, frequencies of acute or chronic GVHD and the incidence of relapse were similar in the male and female groups ( $\mathrm{p}>$ 0.05) (Table 1).
Fertility Status Prior to and After Transplantation

Thirty patients $(28 \%)$ in our cohort had a child, whereas 19 patients/patient partners (18\%) had a history of pregnancy complications prior to the transplantation. Seventy-nine patients or their spouses $(74 \%)$ reported using at least one birth control method during the pre-transplant period, most commonly an intra-uterine device. None of the patients/partners of patiens were using any contraception method post-tranplant. During the pretransplant period, there were 14 spontaneous abor- 
Table 2. Clinical characteristics and pregnancy complications of survivors reporting pregnancies after allo-HSCT

\begin{tabular}{|c|c|c|}
\hline \multicolumn{2}{|l|}{ Variables } & \multirow{2}{*}{ Female $(n=$} \\
\hline Pregnancy outcomes, n (\%) & & \\
\hline Live births & $6(100 \%)$ & $18(90 \%)$ \\
\hline Miscarriage & $1(17 \%)$ & $8(30 \%)$ \\
\hline Stillbirth & $1(17 \%)$ & $1(5 \%)$ \\
\hline \multicolumn{3}{|l|}{ Pregnancy complications, n (\%) } \\
\hline Preeclampsia & $1(17 \%)$ & - \\
\hline Gestational diabetes & $1(17 \%)$ & $1(5 \%)$ \\
\hline Gestational hypertension & - & $1(5 \%)$ \\
\hline Mean time to pregnancy, months (range) & $63(8-108)$ & $68(4-144)$ \\
\hline Median Age at first post-HCT pregnancy, years (range) & $30(22-38)$ & $32(22-48)$ \\
\hline \multicolumn{3}{|l|}{ Diagnosis, n (\%) } \\
\hline Acute leukemia & $1(17 \%)$ & $9(45 \%)$ \\
\hline Chronic myeloproliferative disease & $1(17 \%)$ & $10(50 \%)$ \\
\hline Bone marrow failure & $4(66 \%)$ & $1(5 \%)$ \\
\hline \multicolumn{3}{|l|}{ Conditioning Regimen, n (\%) } \\
\hline Cyclophosphomide & $6(100 \%)$ & 20 (100\%) \\
\hline ATG (antithymocyte globulin) & $4(66 \%)$ & $1(5 \%)$ \\
\hline Fludarabine & $1(17 \%)$ & $1(5 \%)$ \\
\hline Busulphan & $2(34 \%)$ & $17(85 \%)$ \\
\hline TBI (total body irradiation) & - & $1(5 \%)$ \\
\hline
\end{tabular}

tions. Nine of 44 female patients (20\%) had regular menstrual cycles after transplantation. $6 / 9$ patients $(66 \%)$ were diagnosed with benign hematological diseases. Serum hormonal levels were measured in 19 out of 44 patients. Despite the presence of menstrual cycles in 9 patients, elevated FSH (median $46 \mathrm{IU} / \mathrm{L}$; range 3-87) and LH levels (median 32 IU/L; range 1-62) were detected. Serum FSH, LH and testosterone levels and spermiogram were analyzed in 29 of 63 male patients and resulted within normal range.

A total of 26 (24\%) survivors reported 35 postHSCT conceptions; these included $20(45 \%)$ male survivors and $6(14 \%)$ female survivors (Table 2). 3 of 6 female survivors had spontaneous menstrual cycles. Outcomes of post-HCT conceptions included 24 live births (69\%), 9 miscarriages (26\%), and 2 stillbirths (5\%). All of the female recipients achieved pregnancy without assistance; however, two male patients did have children with in vitro fertilization. The median duration of pregnancy in the female survivors was $37.67 \pm 2.07$ weeks compared to partners of male survivors at $38.31 \pm 1.62$ weeks. No preterm deliveries were observed in either group. Cesarean (C/S) and normal delivery rates were equal in frequency in female patients $(50 \%)$, whereas partners of male patients had more $\mathrm{C} / \mathrm{S}$ deliveries ( $55 \%$ vs $45 \%$ ). The median weight of child at birth was $3.10 \pm 0.81 \mathrm{~kg}$ in female patients and $3.30 \pm 0.63$ in male patients. A low birth weight child was detected in $1(17 \%)$ female pregnancy and in $6(33 \%)$ pregnancies of partners of male transplant recipients ( $p>0.05)$. Two children of partners of male recipients had congenital abnormalities, including 1 dysmorphic ear and 1 cardiac vein anomaly.

All patients who gave birth after allo-HSCT had received transplants from full-match HLA sibling donors or relatives. A myeloablative conditioning regimen was chosen in 25 survivors, and 1 male 
International Journal of Hematology and Oncology

\begin{tabular}{|c|c|c|c|}
\hline Variables, n (\%) & Fertile $(n=26)$ & Infertile $(n=81)$ & p \\
\hline Age $\geq 30$ at alloHSCT & $8(31 \%)$ & 59 (73\%) & $<0.0001^{*}$ \\
\hline Male/Female & 20 (77\%) /6 (23\%) & $43(53 \%) / 38(47 \%)$ & $0.032^{*}$ \\
\hline Median age, years (range) & $40(23-53)$ & $43(22-59)$ & $0.02^{*}$ \\
\hline Age at diagnosis, years (range) & $26.5(16-39)$ & $35(16-45)$ & $<0.0001^{*}$ \\
\hline \multicolumn{4}{|l|}{ Diagnosis, n (\%) } \\
\hline Acuteleukemia & $10(38 \%)$ & 47 (58\%) & $0.025^{\star}$ \\
\hline Chronic myeloproliferative disease & $11(42 \%)$ & $21(26 \%)$ & \\
\hline Bone marrow failure & $5(19 \%)$ & $5(6 \%)$ & \\
\hline Other & - & $8(10 \%)$ & \\
\hline \multicolumn{4}{|l|}{ Donor type } \\
\hline Relative/Non-Relative & $26(100 \%) /-$ & 77 (95\%) /4 (5\%) & 0.57 \\
\hline \multicolumn{4}{|l|}{ Pre-transplant therapy, n(\%) } \\
\hline Chemotherapy & 20 (77\%) & 74 (91\%) & 0.07 \\
\hline Radiotherapy & - & $3(3 \%)$ & 1.0 \\
\hline \multicolumn{4}{|l|}{ Conditioning regimen, n(\%) } \\
\hline ATG (antithymocyte globulin) & $5(19 \%)$ & $12(15 \%)$ & 0.59 \\
\hline Cyclophosphomide & $26(100 \%)$ & $72(88 \%)$ & 0.10 \\
\hline Fludarabine & $2(7 \%)$ & $11(14 \%)$ & 0.73 \\
\hline Busulphan & 19 (73\%) & $63(77 \%)$ & 0.06 \\
\hline TBI (total body irradiation) & $1(4 \%)$ & $12(15 \%)$ & 0.18 \\
\hline Relapse after Allo-HSCT & $3(12 \%)$ & 28 (35\%) & $0.026^{*}$ \\
\hline Acute GvHD & $9(35 \%)$ & 31 (38\%) & 0.74 \\
\hline Chronic GvHD & $14(54 \%)$ & 50 (62\%) & 0.48 \\
\hline \multicolumn{4}{|l|}{ Stem Cell Source } \\
\hline Bone Marrow & 16 (62\%) & $10(12 \%)$ & $0.001^{*}$ \\
\hline Peripheral Blood & 10 (38\%) & $62(88 \%)$ & \\
\hline
\end{tabular}

patient had reduced intensity conditioning. The conditioning regimens were: Busulphan (BU) 3.2 $\mathrm{mg} / \mathrm{kg} /$ day plus cyclophosphamide (CY) $60 \mathrm{mg} /$ $\mathrm{kg} / \mathrm{day}(73 \%)$, cyclophosphamide $50 \mathrm{mg} / \mathrm{kg} / \mathrm{day}$ plus antithymocyte globulin (ATG) $30 \mathrm{mg} / \mathrm{kg} /$ day (11\%), Fludarabine (Flu) $30 \mathrm{mg} / \mathrm{m}^{2} /$ day plus CY $60 \mathrm{mg} / \mathrm{kg} /$ day plus ATG $10 \mathrm{mg} / \mathrm{kg} /$ day (4\%), CY 60 $\mathrm{mg} / \mathrm{kg} /$ day plus TBI 2 × 2 Gy/day (4\%), Flu $30 \mathrm{mg} /$ $\mathrm{m}^{2} /$ day plus BU $4 \mathrm{mg} / \mathrm{kg} /$ day plus ATG $10 \mathrm{mg} / \mathrm{kg}$ / day (4\%), CY $60 \mathrm{mg} / \mathrm{kg} / \mathrm{day}$ (4\%). The stem cell source was bone marrow in 4 fertile female patients
(66\%) and $12(60 \%)$ male patients. Acute/chronic GVHD was detected in $2(33 \%) / 2(33 \%)$ female survivors and $7(35 \%) / 12(60 \%)$ male survivors. The partners of 3 of the male recipients $(15 \%)$ reported pregnancy after disease relapse. Sperm cryopreservation was utilized in only 2 male survivors and ovarian cryopreservation was utilized in 1 female survivor, but attempts for pregnancy were not reported in these patients. 


\section{Comparison of Fertile and Unfertile Patients}

Comparisons of several parameters between fertile vs unfertile patients are shown in Table 3 . Age $\geq 30$ at the time of allo-HSCT was associated with increased risk of infertility ( $31 \%$ vs $73 \%$, p $<0.0001$ ). The partners of male patients had more pregnancies than the female patients ( $77 \%$ vs $53 \%, \mathrm{p}=0.032)$. The median age at both study participation and diagnosis were found to be statistically higher in the infertile group ( 40 vs $43, \mathrm{p}=0.02 ; 26.5$ vs $35, \mathrm{p}<$ $0.0001)$. Malignant hematological diseases rather than chronic myeloproliferative disease (CMPD) and bone marrow (BM) failure also had increased risk of infertility (38\% vs $55 \%, \mathrm{p}=0.025)$. The fertile patients relapsed after allo-HSCT less frequently than the infertile patients ( $12 \%$ vs $35 \%$, $\mathrm{p}=0.026$ ). Stem cell source of bone marrow was found to be associated with increased fertility outcome $(62 \%$ vs $12 \%, \mathrm{p}=0.001 *)$.

Fertility was not found to be related to donor type, pretransplant chemotherapy or radiotherapy, conditioning regimen including cyclophosphomide, fludarabine, busulphan, TBI or acute/chronic GVHD ( $>>0.05)$.

\section{DISCUSSION}

Successful pregnancies have been reported in female HCT patients and female partners of male HCT patients. Salooja et al investigated the pregnancy rates of nearly 38,000 transplant patients (autologous and allogeneic) by sending questionnaires to 199 centers. They reported 312 pregnancies from 232 patients for an overall conception rate of $0.6 \%$. (6). In 2006, Bone Marrow Transplant Survivor Study (BMTSS) reported the pregnancy outcomes of 619 HCT survivors and partners and compared these outcomes with those of the patients' nearest age siblings. There were 54 pregnancies reported from $34(5.5 \%)$ patients ( 26 female, 8 male) with 46 live births and an overall lower prevalence of conception compared to their siblings. The median age at study participation was 42.6 years (range 23.3-60.4 years), whereas the median age at transplant was 33.3 years (21.0-45.0) (7). In our study, a total of 26 (24\%) survivors reported 35 post-HCT conceptions from 107 participants. These included $20(45 \%)$ male survivors and $6(14 \%)$ female survivors. The overall conception rate was higher than in previous studies, which may have occurred because our study contains a homogenous cohort of patients who were truly of child-bearing age and were interested in conceiving children. Consistent with this hypothesis, the median age at both study participation and allo-transplantation was lower than in the previous reports. Younger age is associated with an increased likelihood of fertility recovery. ${ }^{2}$ Previous studies indicated that fertility is most frequently preserved in patients receiving a transplant in the young adult age group (15-30 years). ${ }^{8}$ This was supported by our study, which showed that age $>30$ years at Allo-HSCT was related to increased risk of infertility.

Center for International Blood and Marrow Transplantation Research (CIBMTR) data included 178 pregnancies ( 83 female, 95 female partners of HCT recipients) with a median age at pregnancy similar to that in our study. In addition, in both women and partners of men receiving myeloablative HCT the median time to pregnancy was 7 years after HCT in the CIBMTR data. ${ }^{8}$ We report shorter median time to pregnancy after allo-HCT in partners of male survivors (68.15 months) and female survivors (63.33 months). A partner of one male patient conceived 28 months after allo-HST. These time periods are consistent with the observation that spermatogenesis recovers in $20 \%$ to $25 \%$ of HCT patients after prolonged follow-up. ${ }^{4}$ Longer follow-up is important if fertility is desired.

Central or peripheral gonadal failure are frequent complications of allo-HSCT that cause infertility. The probability of recovery of ovarian function declines by 0.8 per year with increasing age at transplantation. ${ }^{9}$ Gonadal failure depends on several factors including the age of the patient, the type of chemotherapy and total body irridation (TBI). The conditioning regimen for HSCT usually consists of TBI with 12-14 Gray (Gy) and chemotherapy with cyclophosphamide (CY), etoposide (VP) or combination of busulfan (BU) and CY. ${ }^{10}$ All antineoplastic drugs, especially alkylating agents, have dose-dependent toxic effects on both oocytes and granulosa cells. ${ }^{11,12}$ Alkylating agents can damage primordial follicles through apoptotic cell death, resulting in destruction of ovarian reserve. ${ }^{13} \mathrm{Al}-$ though BU is considered to be highly gonadotoxic, especially in women, there are conflicting results 
and different diagnoses. ${ }^{10}$ In men, both alkylating agents and irradiation were found to be gonadotoxic to germ cell epithelium and Leydig cells in the testis. ${ }^{14}$ We did not detect a fertility advantage for any specific conditioning regimen or TBI. In fact, only 1 of fertile patients received reduced intensity regimen and 1 received high dose TBI which is not sufficient to detect the impact of reduced intensity regimen or TBI on fertility.

Female allograft patients have been reported to have higher rates of ceaserean section, preterm delivery and low birthweight babies than a control population. ${ }^{6}$ However, BMTSS did not find a higher prevalence of preterm births after HCT than in the sibling comparison group, a finding that is similar to that of our study. ${ }^{7}$

It should be stated that there are drawbacks of this study. The study was designed retrospectively which involved missing data of patients'/patient partners' hormone levels. Since, we don't have adequate data about fertility prior to transplantation, it is also possible that partners of the patients but not the patients themselves may be infertile.

Two partners of our patients conceived with assisted reproductive technologies (ARTs) which have been recently evolving such as in vitro fertilization-embryo transfer, gamete intrafallopian transfer, zygote intrafallopian transfer and frozen embryo transfer. Currently, fertility preservation should be considered prior to cytotoxic treatments. Sperm cryopreservation is an option for male patients. Female patients have more options to consider, including ovarian cortex freezing, oocyte cryopreservation after conventional in vitro fertilization stimulation, in vitro fertilization and embryo freezing, drug-based preservation with gonadotropin releasing hormone (GnRH) agonists and transposition of the ovaries prior to radiotherapy, which are all techniques of fertility preservation. ${ }^{15}$

\section{CONCLUSION}

Treatments prior to Allo-HSCT may have damaging effects on gonadal tissue and induce infertility as previously reported. A benign nature of the initial diagnosis, early age at diagnosis and at AlloHSCT, no relapse of the primary disease, and a bone marrow stem cell source are associated with fertility in our study. Unexpectedly, we found no relationship of infertility to the myeloablative conditioning regimen, radiotherapy/chemotherapy prior to Allo-HSCT, TBI usage and frequency, donor type or development of acute and chronic GVHD.

\section{REFERENCES}

1. Pulsipher MA, Skinner R, McDonald GB, Hingorani S, Armenian SH, Cooke KR, Gracia C, Petryk A, Bhatia S, Bunin N, Nieder ML, Dvorak CC, Sung L, Sanders JE, Kurtzberg J, Baker KS, National Cancer Institute, National Heart, Lung and Blood Institute/Pediatric: Blood and Marrow Transplantation Consortium First International Consensus Conference on late effects after pediatric hematopoietic cell transplantation: the need for pediatric-specific long-term follow-up guidelines. Biol Blood Marrow Transplant 18: 334-347, 2012.

2. Borgmann-Staudt $A$, Rendtorff $R$, Reinmuth $S$, et al. Fertility after allogeneic haematopoietic stem cell transplantation in childhood and adolescence.Bone Marrow Transplantation 47: 313-314, 2012.

3. Apperley JF, Reddy N. Mechanism and management oftreatment-related gonadal failure in recipients of high dosechemoradiotherapy. Blood Rev 9: 93-116, 1995.

4. Rovo A, Tichelli A, Passweg JR, Heim D, Meyer-Monard S, Holzgreve $W$ et al. Spermatogenesis in long-term survivors after allogeneic hematopoietic stem cell transplantation s associated with age, time interval since transplantation, and apparently absence of chronic GVHD. Blood 108: 1100-1105, 2006.

5. Gulati SC, Van Poznak C. Pregnancy after bone marrow transplantation. J ClinOncol 16: 1978-1985,1998.

6. Salooja N, Szydlo RM, Socie G, et al. Pregnancy outcomes afterperipheral blood or bone marrow transplantation: a retrospective survey. Lancet 358: 271-276, 2001.

7. Lee SJ, Schover LR, Partridge AH, et al. American Society ofClinical Oncology recommendations on fertility preservation in cancer patients. J ClinOncol 24: 2917-2931, 2006.

8. Assouline E, Crocchiolo R, Prevet T et al. Impact of ReducedIntensity Conditioning Allogeneic Stem Cell Transplantation on Women's Fertility. Clin Lymphoma, Myeloma Leuk 13: 704710, 2013.

9. Cheng YC, Saliba RM, Rondon G, et al. Low prevalence of premature ovarian failure in women given reduced-intensity conditioning regimens for hematopoietic stem-cell transplantation. Haematologica 90: 1725-1726, 2005.

10. Bakker B, Oostdijk W, Bresters D, et al. Disturbances of growth and endocrine function after busulphan-based conditioning for haematopoietic stem cell J Cancer Res ClinOncolransplantation during infancy and childhood. Bone Marrow Transplant 33: 1049-1056, 2004. 
International Journal of Hematology and Oncology

11. King J, Wynne $\mathrm{CH}$, Assersohn L, et al. Hormone replacement therapy and women with premature menopause. Eur J Cancer 47: 1623-32, 2011.

12. Amarante F, Vilodre LC, Maturana MA, et al. Women with primary ovarian insufficiency have lower bone mineral density. Braz J Med Biol Res 44: 78-83, 2011.

13. Bines J, Oleske DM, Cobleigh MA. Ovarian function in premenopausal women treated with adjuvant chemotherapy for breast cancer. J Clin Exp Oncol 14: 1718-1729,1996.

14. Salooja N, Szydlo RM, Socie G, et al. Pregnancy outcomes after peripheral blood or bone marrow transplantation: a retrospective survey. Lancet 358: 271-276, 2001.

15. Letourneau JM, Ebbel EE, Katz PP, et al. Pretreatment fertility counseling and fertility preservation improve quality of life in reproductive age women with cancer. Cancer 118: 1710-1717, 2012.

\section{Correspondence}

\section{Dr. Pervin TOPCUOGLU}

Ankara Üniversitesi Tip Fakültesi

Hematoloji Anabilim Dali,

Kemik Iligi Transplantasyon Birimi

Cebeci Hastanesi

06590 Dikimevi, ANKARA / TURKEY

Tel: (+90-312) 5957099

Fax: (+90-312) 5957482

e-mail: topcuoglupervin@gmail.com 